シンポジゥム -4

骨肉腫の治療

術前のアドリアマイシン大量間歇動注と

患肢を温存した広汎切除術について

福岡大学整形外科

$\begin{array}{ccccc}\text { 葉 } & \text { 山 } & \text { 泉・高 岸 直 人 } \\ \text { 諌 山 } & \text { 照 } \text { 刀・桜 井 } \text { 日出也 } \\ \text { タケシマ整形外科 } & & & & \\ \text { 竹 嶋 康 弘 } & & \end{array}$

\title{
Treatment of Osteosarcoma
}

(Preoperative intermittent arterial infusion of high dose adriamycin and wide resection of tumor)

by

S. Yoh, N. Takagishi, T. Isayama, H. Sakurai

Faculty of Medicine, Fukuoka University, Japan

Y. Takeshima

Department of Orthopaedic Surgery Takeshima Hospital

\begin{abstract}
Amputation for two cases and wide resection for a case of Osteosarcoma who were decreased tumor growth by preoperative intermittent arterial infusion of high dose adriamycin is described.

It may be effective to prevention against pulmonary metastasis that high dose adriamycin infusion into the central vein or pulmonary artery.
\end{abstract}

福岡大学病院開設以来の骨軟部腫瘍の入院患者総数 は骨腫瘍 86 例, 軟部腫瘍 64 例の計 160 例であり, こ のうち骨肉腫は 6 例である.

これらの治療成績を報告し, 現在われわれが行なっ ている術前の ADM 大量間歇動注法 (one shot 注 入）と患肢を温存した広範切除術の可能性について， われわれの考え方を述べたい.

\section{治療法と予後}

症例は男女各々 3 名で, 年令は 7 才から 55 才, 原 発部位は大腿骨 3 例, 上腕骨, 腸骨, 腰椎の各 1 例で ある．治療法は根治手術を原則としているが，手術不 能な脊椎や, 初診時すでに広汎な転移が認められたす のには放射線治療を施行した. 全例に化学療法を併用
しており，うち 3 例には術前の ADM 大量間歇動注 を施行した。転移は肺転移 3 例，骨転移 1 例で，転移 が認められないのは 2 例にすぎない. 生存例は 3 例 で, うち 1 例には肺転移が認められる (表 1 一上).

昭和 52 年以降の福大における骨肉腫の化学療法は, 国立がんセンター福間らの VCR, CQ の術前持続動 注と ADM の術前間歇動注及び術後の ADM 大量間 歇全身投与の変法である. 即ち主幹動脈分枝より硬麻 チューブを挿入留置し, VCR $1 \mathrm{mg}, \mathrm{CQ} 3 \mathrm{mg}, \mathrm{MDS}$ $600 \mathrm{mg}$ の動注下に生検を施行し，1 週間後の創治癒 と組織診断を待って, UK, MDS を併用した ADM $0.8 \mathrm{mg} / \mathrm{kg}$ の大量間歇動注（one shot 注入）を連 続 3 回 1 クールを施行. 血液像の改善がみられる $3 \sim$ 4 週後の自覚症状の改善と腫瘤の縮小がみられたとと 
ろで根治手術を施行. ADM 動注後より手術までの休 薬期間にも VCR, CQ を間歇動注し，術後は ADM の 全身大量間歇投与（中心静脈または肺動脈注入）を 2 クール，その後は半量の全身投与（one shot 静注） を 1 力月間隔で約 1 年間続けることにしている．根治 手術は，化学療法勃果として腫瘤の縮小がみられたも ので, 術後の組織欠損の部位, 程度により, 機能的な 四肢の残存が可能と思われる場合には，積極的に患肢 を温存した広汎切除術を施行するてとを原則としてい る (表 1 -下).

（症例 $4 ） 21$ 才，女，左大腿骨々肉腫（図 1）

5 力月前に膝関節痛, 2 力月前に同部の腫脹に気付
き，近医を受診し当科を紹介された．初診時は左膝上 部内側の腫脹及び運動痛が認められ，単純レ線で大腿 骨遠位骨幹端部の骨吸収陰影がみられ，C Tでは骨骾 内の不規則な斑状硬化を伴った腫瘤陰影が骨皮質を破 り，前内側及び 後側には骨外腫瘾を 形成している. VCR $1 \mathrm{mg}, \mathrm{CQ} 3 \mathrm{mg}$, MDS $600 \mathrm{mg}$ 動注下の生検 にて Osteoosarcoma の組織診断を得たので, 同量の $\mathrm{VCR}, \mathrm{CQ}, \mathrm{MDS}$ を 2 回, ADM $20 \mathrm{mg} 1$ 回を間歇動 注したところで，ADM の大量間歇動注を施行した.

即ち MDS $600 \mathrm{mg}$ に続いて ADM $40 \mathrm{mg}(0.9 \mathrm{mg}$ / $\mathrm{kg}$ ）の間歇動注を連続 3 日間 1 クールを施行し手術ま で休薬した. 入院時の腫瘤部大腿周径 $32.5 \mathrm{~cm} \mathrm{が}$

\begin{tabular}{|c|c|c|c|c|c|c|c|c|}
\hline 症例 & 性 & 年 令 & 原発果 & 放治 & 化学 療 法 & 手 術 & 転 程 & 予 後 \\
\hline 1 & 男 & 42 & 晹骨 & ${ }^{60} \mathrm{Co}$ & Ex, VCR & $(-)$ & 肺 $(0)$ & $\mathbb{Z}(1)$ \\
\hline 2 & 男 & 19 & 腰椎 & ${ }^{60} \mathrm{Co}$ & $V C R, C Q, A D M$ & $(-)$ & 骨( 5$)$ & 叉(11) \\
\hline 3 & 男 & 14 & 大腿骨 & $(-)$ & ADM & 切 断 & 肺 (21) & 叉(24) \\
\hline 4 & 女 & 21 & 大格骨 & $(-)$ & $\mathrm{VCR}, \mathrm{CQ}, \mathrm{ADM}$ * & 切 断 & $(-)$ & 生存 (26) \\
\hline 5 & 女 & 55 & 上腕骨 & $(-)$ & VCR, $C Q, A D M *$ & 広 切 & 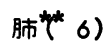 & 生存 (11) \\
\hline 6 & 女 & 7 & 大腿魚 & $(-)$ & $A D M *, \quad M T X, V C R, C Q$ & $\begin{array}{c}(\text { ) } \\
\text { 丸山ワクチン }\end{array}$ & $(-)$ & 生存( 6) \\
\hline
\end{tabular}

福大における鲁肉自治法
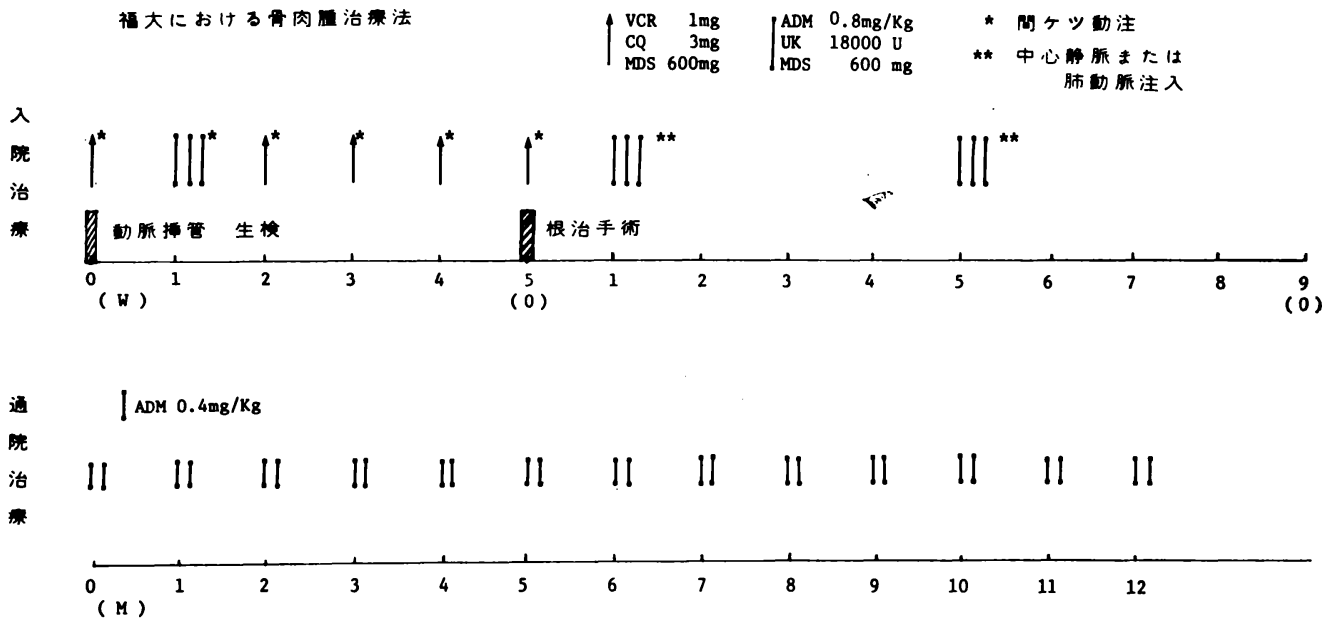

表 1 治 療 法と予後 
$\mathrm{ADM}$ 大量間歇動注時には $35 \mathrm{~cm}$ と增大していたが， 4 週間後の手術時には $31 \mathrm{~cm}$ と縮小し, 自・他覚症 状の改善がみられた。しかし，レ線でみる限りでは， 骨破壊が進行したので大腿切断術を施行した. 腫瘍の 横断割面では，骨䯣内に充満した，一部に囊牌様変化 を伴う海綿様組織が骨皮質を破壊し骨外腫瘤を形成し ているむのの，骨膜様被膜に包まれており，血管神経 束と筋組織を容易に剥離する事ができた. 組織学的に 6広汎な变性壊死組織が充満しており，生きた腫瘍細 胞を認めることができなかった. 術後は前述の如き $\mathrm{ADM}$ の全身投与を行ない，26力月の現在，肺転移 あなく生存している. 本例は患肢を温存した広汎切除 術が可能であったのではないかと考えている。
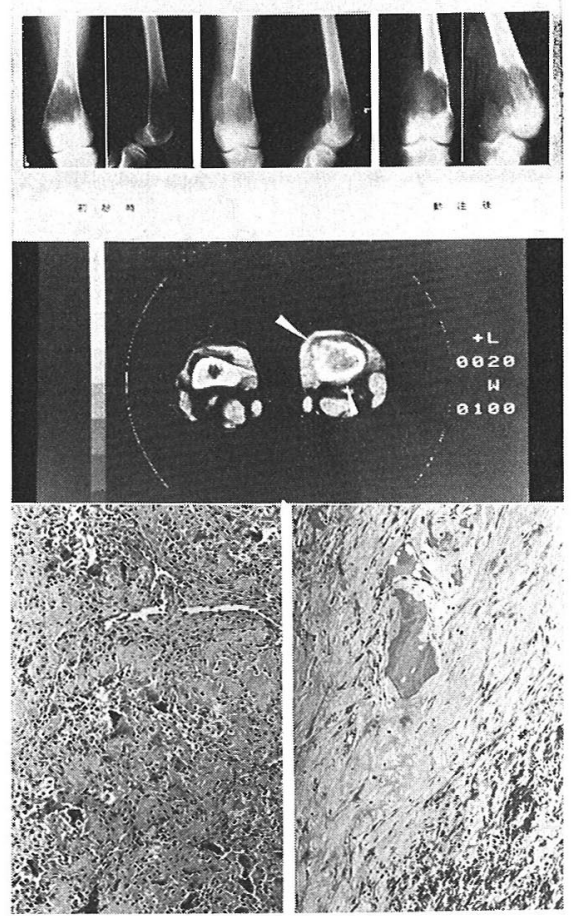

図 1 症例 4 組織は左が生検時, 右が手術時のもの （症例 5 ） 55 才，女，右上腕骨々肉腫（図 2 ）

本例は前回の本学会で報告した症例で, $\mathrm{VCR}, \mathrm{CQ}$, MDS 動注下の生検と, MDS, UK と併用した ADM $40 \mathrm{mg}(0.6 \mathrm{mg} / \mathrm{kg})$ の連続 3 日間 1 クールの間歇動 注にて，著明な腫瘤の縮小之疼痛の緩解がみられた ので，上肢を温存した広汎切除術 Inter scapulothoracic resection を施行した. 切除標本では，大 きな 変腫様変化を伴った変性壊死組織が 充満してお
り，生きた腫瘍細胞は辺縁に少量認められたのみであ る. 術後の残存肢の機能は良好で, 肩の外転, 内旋も 可能で肘伸展力の低下以外末梢は正常で, 書字, 食 事，着衣動作など殆んど患肢を使用しており，高岸の 肩関節機能評価も 16 から $46+\alpha$ と上昇し，患者むわ れわれも満足している. 本例は肥満体であり，1回投 与量が $0.6 \mathrm{mg} / \mathrm{kg}$ で， $0.8 \mathrm{mg} / \mathrm{kg}$ に達しなかった事 と，遠方のために術後の $\mathrm{ADM}$ 投与が 2 クールのみ で終った事が反省される点で, 術後 5 力月と 8 力月に 右肺転移巣が出現した. とれに対しては 2 回にわた り, 肺葉部分切除術 $\left(\mathrm{S}_{8}\right)$ と下葉切除術 $\left(\mathrm{S}_{6}, \mathrm{~S}_{8}\right)$ を 施行. 術後は Hyper alimentation を応用し, 中心 静脈に留置したチューブより $\mathrm{ADM}, \mathrm{MTX}, \mathrm{EX}$ を注 入している.なお, 術後 10 力月の現在局所再発は認 められない。

（症例 6） 7 才，女，左大腿骨々肉腫（図 3）

半月前に発症, 近医より当科を紹介されたが，某大 学整形外科に緊急入院, ADM の大量間歇動注（総量 $51 \mathrm{mg}$ ) 後に小览科で MTX の超大量療法（7 回, $100 \mathrm{mg} / \mathrm{kg}$ から $300 \mathrm{mg} / \mathrm{kg}$ まで増量）をうけ， 腫瘤の縮小と疼痛の緩和をみて一時退院. その後も MTX の超大量療法（2回）をうけたが，腫溜の増大 と疼痛の増強をきたし, 切断術を铨められるむ拒否. 近医にて丸山ワクチンのみ投与をうけていたが病的骨 折をおこし緊急入院. 入院時は左大腿遠位部の腫脹と

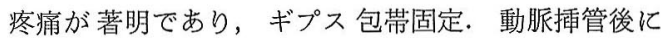
VCR $1 \mathrm{mg}, \mathrm{CQ}$ 1 2 mg, MDS $600 \mathrm{mg}$ の間歇動注 3 回, ADM $16 \mathrm{mg}(0.8 \mathrm{mg} / \mathrm{kg})$ の大量間歇動注を 3 回 1 クールを施行. 3 週間後より腫溜の縮小と自・ 他覚症状の改善がみられ，4週後には腫瘤部大腿周径 は $37.4 \mathrm{~cm}$ にまで縮小した. この時点で根治手術を 勧めたが母親は丸山ワクチンの効果と判断し, 以後の 化学療法をも拒否しつづけた. しかしそれ以後は再び 腫瘤は増大し続け， 4 週間の間に $46 \mathrm{~cm}$ に達した. そとでやっと切断術を承諾したのでこれを施行した。 現在肺転移は認められない。

$\mathrm{ADM}$ 大量間歇動注 8 週後の切除標本は孁腫様変化 を伴う大きな中心性壊死が認められるが，組織学的に は生きた腫瘍細胞が広範囲に認められる。

$$
\text { 考察 }
$$

骨肉腫の治療は根治手術が主体をなしいいるすの の，即時または早期切断術のみでは決して良好な成績 


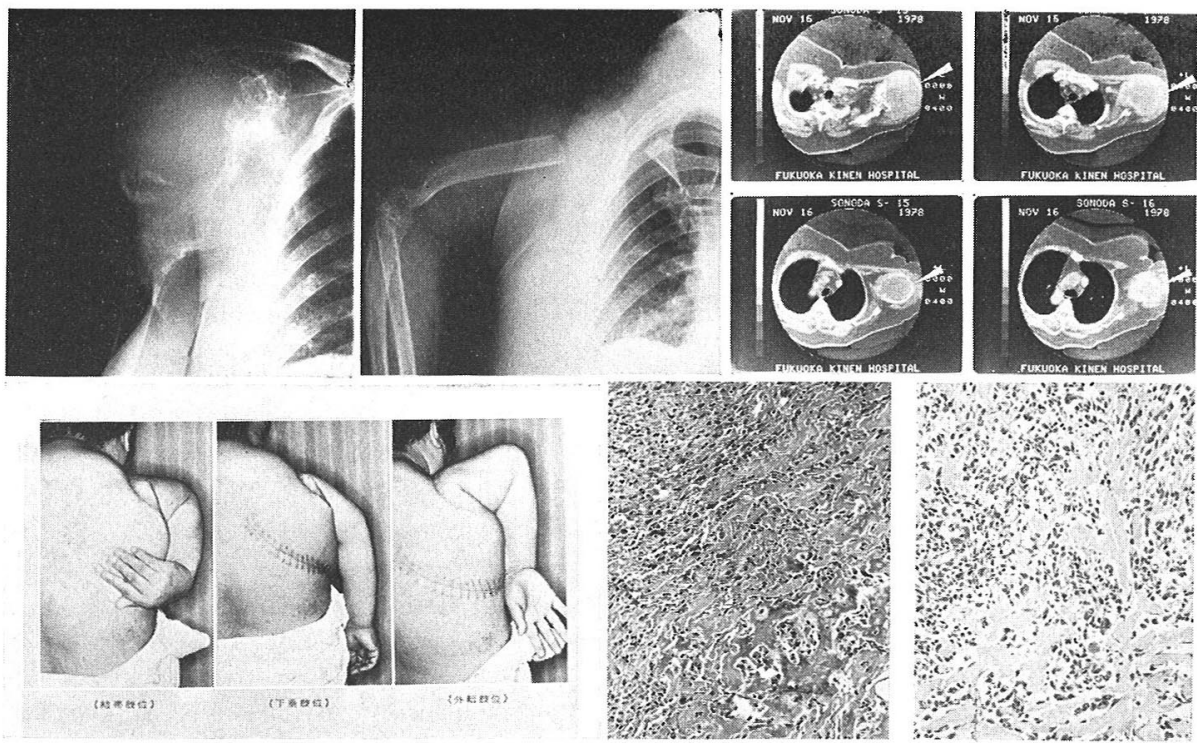

図2症例 5 組織は左が生検洔, 右が手術時のもの
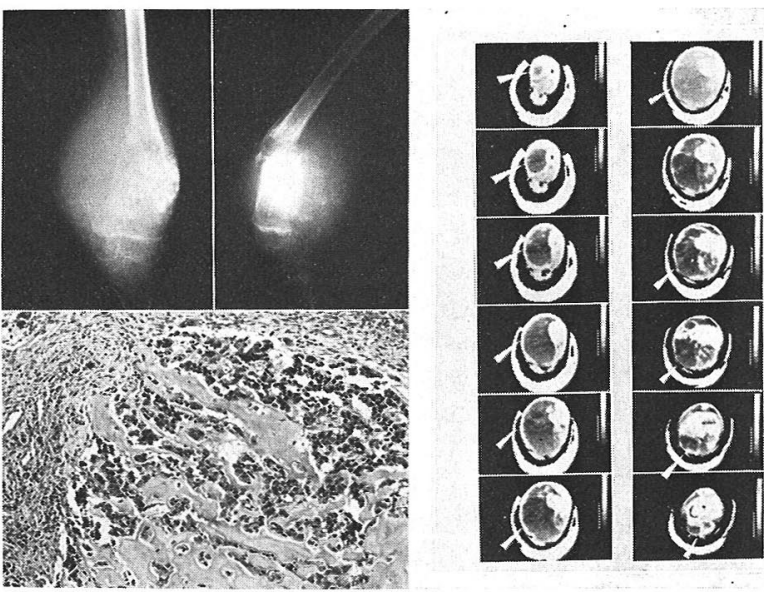

図 3 症例 6 組織は手術洔のむの

を得ることができない.

術前処置として，放射線療法や化学療法などが併用 されているが, ADM と MTX の大量間歇投与法の 開発は化学療法への期待を一層強くした観がある.

肺転移の予防として，試験開胸，全肺野照射などの 報告があるが，決して有効な手段とは考えられない. 上半身動注は理論的にすぐれた方法で，良好な成績が 報告されているが，1回限りに終わるという欠点があ る. われわれは，Hyperalimentation の手技を応用 し，中心静脈または肺動脈に留置したチューブにて高
濃度の抗癌剤を肺動脈に到達させる事を考 虑している．この方法は手技が簡単で，頻 回投与が可能であるという利点がある.

また，現在われわれが施行している $\mathrm{VCR}, \mathrm{CQ}$ 及び大量の ADM の術前間歇動 注法は 3 例に達して拈り，全例に腫瘤の縮 小と自覚症状の改善がみられ，4週後に手 術をした 2 例では，組織学的にも有効であ った事が確認された. ADM の投与量は $0.8 \mathrm{mg} / \mathrm{kg}$ は必要のようである. この事 は骨肉腫に対する患肢を温存した広汎切除 術の適応範囲を拡大していくものと思う.

そのためには, 早期発見, 早期治療が必要 である事はもちろん，腫溜の局在状態を正 確に把握し, 術後の骨欠損部の補填法に工夫が必要之 思われる. 後者に対しては, micro vascular surgery や ceramic の発達が期待されるし，前者には CT scan の応用が考えられる. C T は骨外腫嵧をむ 明確に描出し，その局在状態を立体的に認識する事が 可能になるので, 広汎切除術の術前検査として非常に 有用である. われわれは，CT所見による腫溜の占居 部位と浸潤度に組織型を組み合わせて手術難易度分類 即ち A B C 分類を試み，治療方針の決定に役立ててい る. 症例 $4 ， 5 ， 6$ はそれぞれ $\mathrm{AB}^{\prime} \mathrm{C}, \mathrm{BB}^{\prime} \mathrm{C}, \mathrm{CB}^{\prime} \mathrm{C}$ 
type であり, 症例 4, 5 では血管, 神経束の剝離温 存が可能と推测される（図 1，2，3）.

$$
\text { ま と め }
$$

1. 骨肉腫 3 例に対し, 術前の ADM 大量間歇動 注にて全例に腫瘤の縮小と疼痛の緩和をみた. 動注後 4 週で手術した 2 例は組織学的にあ化学療法効果が認 められた.

2. 2 例に切断術，1例に患肢を温存した広汎切除 術を施行, 後者に肺転移を認め肺葉切除を施行, 全例 局所再発は認められない. 全例生存中である.

3. 肺転移予防として ADM の中心静脈または肺 動脈注入は有効と思われる.

\section{参 考 文 献}

1）赤星義彦: Chronometri Infusor 悪性骨腫湟 の治療への応用, 臨整外, 1:315-319, 1966.

2) Burwell, H. N.: Resection of the Shoulder with Humeral Suspension for Sarcoma Inrolving the Scapula, J. Bone \& Joint Surg. 47-B: 300-303, 1976.

3) Etcubanas E. et al.: Adjuvant Chemotherapy for Osteogenic Sarcoma, Cancer Treat. Rep. 62: 283-287, 1978.

4) 福間久俊ほか：骨腫瘍の肺転移, 肺と心 : 23 : 229-236, 1976.

5）福間久俊ほか：骨肉腫の治療成積一持続動脈内 制癌注入例を中心に一日癌治, 11 ：568-569, 1976.

6)増田元彦ほか：四肢悪性腫瘍に対する動脈内持 続注入法, 癌の癌床, 10:344-, 1964.

7) 仁井谷久暢：抗癌剂と lysome labilizer の併 用, 最新医学, 28: 912-919, 1973.

8）大野藤吉：骨腫場の治療一骨肉腫一, 癌と化学 療法, 6: 481-491, 1979.

9) Rosen, G. et al. : Chemotherapy, En Block Resection, and Prosthetic Bone Replacement in the Treatment of Osteogenic
Sarcoma, Cancer, 37: 1-11, 1976.

10) Rosen, G. et al. : Chemotherapy and Thoractomy for Metastatic Osteogenic Sarcoma, A Model for Adjuvant Chemotherapy and Rationale for the Timing of the Thoracic Surgery, Cancer, 41: 841-849, 1978.

11) Rosen, G. et al.: Primary Osteogenic Sorcoma The Rationale for Preoperative Chemotherapy and Delayed Surgery, Cancer, 43: 2163-2177, 1979.

12) Salzer, M. et al.: Indication for Radical Resection of Malignant Bone Tumors. Results in Forty-Six Cases, Ital. J. Orthop.

Traumatol, 3: 155-166, 1977.

13) Shepp, M. et al.: Adjuvant Treatment of Osteogenic Sarcoma with High-Dose Cyclophosphamide, Cancer Treat. Rep. 62: 295-296, 1978.

14) Sutow W. W. et al.: Adjuvant Chemotherapy in Primary Treatment of Osteogenic Sarcoma A Southwest Oncology Group Study, Cancer, 36: 1598-1602, 1975.

15) Sutow W. W. et al.: Multidrug Adjuvant Chemotherapy for Osteosarcoma: Interim Report of the Southwest Oncology Group Studies, Cancer Treat. Rep. 62: 265-269, 1978.

16）和田武雄ほか：制癌剂効果の増強, 癌の臨床, 17 : 173-177, 1971 .

17）葉山泉ほか：骨軟部腫瘍における Computerized Tomography の応用, 整形外科と災害外 科, 27: 161-163, 1978.

18）葉 山泉ほか：骨軟部腫瘍における Computerized Tomography の応用, 日整会誌, 53: 1394-1397, 1979.

19）葉 山泉ほか：悪性骨軟部腫場に対する患肢を 温存した広沉切除術 (Intercapulo-thoracic resection と Hemipelvic resection の各 1 例), 整形外科と災害外科, 28:411-414, 1979.

20）葉山泉ほか：骨軟部腫瘍における CT と超音 波の応用, 臨床と研究, 57:1127-1138, 1980. 